\title{
Effect of Season and Growing Condition on Biochemical and Physiological Parameters of Coriander (Coriandrum sativum L.)
}

\author{
M. Mohanalakshmi ${ }^{1}$, M. Boomiga* and T. Gowtham ${ }^{2}$ \\ Department of Spices and plantation Crops, \\ Tamil Nadu Agricultural University, \\ Coimbatore, India \\ *Corresponding author
}

\section{A B S T R A C T}

\section{Keywords \\ Coriander, \\ Shadenet, \\ Physiological \\ characters, \\ Biochemical \\ Characters, Year \\ round production \\ Article Info \\ Accepted: \\ 17 July 2019 \\ Available Online: \\ 10 August 2019}

\begin{abstract}
Coriander (Coriandrum sativum L.) is an important spice crop which belongs to the family Apiaceae and originated from Mediterranean Region. This study was conducted at the Department of Spices and Plantation Crops, Horticultural College and Research Institute, Tamil Nadu Agricultural University, Coimbatore during 2017 to study the effect of season of sowing on biochemical and physiological parameters of coriander under two different growing condition viz., open field and shade net $(50 \%)$ with the variety CO (CR) 4 . The experiment was laid out in a Randomized Block Design (RBD) with eighteen treatments replicated thrice. When we see the results, leaf area and leaf area index was high during the month of October in shade condition and September under open conditions. When we see the biochemical parameters like, Nitrate Reductase Activity, Ascorbic acid, SPAD vale and Soluble protein content were not influenced by sowing condition and season of sowing. Hence from this study it can be concluded that, the Physiological characters were influenced by sowing condition and season of sowing but the biochemical characters were not.
\end{abstract}

\section{Introduction}

Coriander (Coriandrum sativum L.) is an important spice crop which belongs to the family Apiaceae and originated from Mediterranean Region. India is the largest producer, consumer and exporter of coriander with a greater share in the world export market. In India, coriander is grown in an area of $6,74,000$ hectares with the production of $8,83,000$ metric tonnes and the productivity of 1.3 metric tonnes per hectare (DASD, 2017).
Estimated export of coriander is 40,100 tones with a total value of 4,48,161 lakhs. Major importers are Malaysia, Pakistan, UAE and Saudi Arabia. In India, Rajasthan $(60 \%)$ is the major producer of coriander followed by Madhya Pradesh, Andhra Pradesh, Karnataka, Tamil Nadu and Odisha.

Coriander is valued for its tender leaves and grains. The seeds and leaves are used for the treatment of indigestion, dyspepsia, flatulence and piles (Dimri et al., 1976). The nutritional 
value of coriander leaves per $100 \mathrm{~g}$ is energy $(100 \mathrm{~kJ})$, moisture $(89.9 \%)$, carbohydrates $(6.5 \%)$, dietary fiber $(27 \%)$, fat $(0.6 \%)$, protein $(3.3 \%)$, total ash (1.7\%), vitamin A (175 i.u./100g), vitamin C $(12.0 \mathrm{mg} / 100 \mathrm{~g})$, calcium $(0.14 \%)$, phosphorus $(0.06 \%)$ and iron $(0.01 \%)$ (Shankaracharya and Natarajan, 1971).

The coriander is a cool season crop and can be successfully cultivated in rabi season on black cotton or other type of heavy soils which have better water retention capacity. Coriander plants are highly sensitive to the abrupt variations in climatic parameters as it is delicate in nature. Hence coriander cultivation during off season under protected structures in which the micro-climate can be modified, to provide optimum condition and to support the survival and growth of plants. Protected cultivation thus facilitate continuous production of leafy coriander throughout the year and off-season crop to fetch higher market rates due to high demand with increased nutrient contents. There is a continuous demand for fresh coriander leaves all-round the year. Hence, the experiment was conducted to assess the performance of coriander var.CO (CR) 4 under shadenet and open field condition for biochemical and physiological characters.

\section{Materials and Methods}

The present investigation was conducted at the Department of Spices and Plantation Crops, Horticultural College and Research Institute, Tamil Nadu Agricultural University, Coimbatore, during the year 2017-2018. The experimental location is situated at $11^{0} \mathrm{~N}$ latitude, $77^{\circ} \mathrm{E}$ longitude and at an altitude of $426.26 \mathrm{~m}$ above MSL. The field experiment was conducted for 9 months from September, 2017 to May, 2018, to study the effect of season of sowing on foliage yield and quality of coriander under two different growing condition viz., open field and shade net (50\%) with the variety variety $\mathrm{CO}(\mathrm{CR}) 4$. The experiment was laid out in a Randomized Block Design (RBD) with eighteen treatments replicated thrice. The treatment details are given in Table 1.

From the tagged plants in each replication, the leaf area of all the leaves were recorded by feeding the leaves into the photosensitive, automatic portable leaf area meter at 40 days after sowing and the mean was expressed in square centimeter. The leaf area index was computed by using the following formula and expressed as $\mathrm{cm}^{2}$ (Williams, 1946).

$$
\text { LAI }=\frac{\text { Leaf area of plant }\left(\mathrm{cm}^{2}\right)}{-} \text { Ground area occupied }\left(\mathrm{cm}^{2}\right)
$$

SPAD meter was used to measure the chlorophyll content of the leaf. It quantifies green colour in plants immediately by non destructive measuring method (Yadava, 1986). The chlorophyll meter computes the SPAD value based on the intensities of light transmitted in the red band (around $650 \mathrm{~nm}$ ) where absorption by chlorophyll is high and in the infrared band (around $940 \mathrm{~nm}$ ) where absorption is low. Nitrate reductase activity was estimated in fully expanded functional leaves at 35 days after sowing as per the method of (Nicholas et al., 1976) and the enzyme activity was expressed as $\mu \mathrm{g} \mathrm{NO} \mathrm{g}^{-1}$ $\mathrm{h}^{-1}$. The leaf protein was estimated at 35 days after sowing as per the method described by (Lowry et al., 1957). The protein content of the sample was expressed as mg $100 \mathrm{~g}^{-1}$ of fresh sample. The ascorbic acid content in coriander leaves was estimated at 35 days after sowing by using the procedure given in Association of Analytical Communities (Anonymous., 1975) and was expressed as mg $100 \mathrm{~g}^{-1}$ of fresh sample. The data were analyzed adopting the standard procedure (Panse and Sukhatme, 1985). 


\section{Results and Discussion}

Effect of different months of sowing and cultivation condition on leaf area $\left(\mathrm{cm}^{2}\right)$ and Leaf Area Index (LAI) were presentedin Table 2. Significant differences in leaf area and leaf area index was observed during different months of sowing under open field condition and shade net condition. The crop grown during October month recorded a maximum leaf area (under shade $40.84 \mathrm{~cm}^{2}$ and open $35.04 \mathrm{~cm}^{2}$ conditions) and leaf area index (under shade 0.136 and open 0.117 condition followed by September month. There was no crop growth during March, April and May under open field condition. Meanwhile minimum leaf area was recorded during these months under shade net $(30.34$ $\mathrm{cm}^{2}, 28.90 \mathrm{~cm}^{2}$ and $38.67 \mathrm{~cm}^{2}$ ). Meanwhile the leaf area index recorded minimum values during three months $(0.101,0.096$ and 0.129$)$ respectively in shade net condition.

Effect of different months of sowing and cultivation condition on SPAD value and Nitrate Reductase Activity were presentedin Table 3. There was no significant variation in SPAD values and nitrate reductase activity during different months of sowing under shade net and open condition with a range of 42.09 (April) to 43.64 (October) in shade net condition and it was observed that the SPAD value was lower in crops grown under open field condition than the crops raised in shade net condition. The highest nitrate reductase activity $\left(321.68 \mu \mathrm{g} \mathrm{NO}_{2} \mathrm{~g}^{-1} \mathrm{~h}^{-1}\right)$ was recorded in the plant raised during the month of January under open condition and the lowest was observed in shade net condition during the month of May $\left(281.66 \mu \mathrm{g} \mathrm{NO}_{2} \mathrm{~g}^{-1} \mathrm{~h}^{-1}\right)$.

Table.1 Treatment combinations

\begin{tabular}{|c|l|}
\hline Treatments & Details \\
\hline $\mathbf{G}_{\mathbf{1}} \mathbf{S}_{\mathbf{1}}$ & Open field condition + Time of sowing (September) \\
\hline $\mathbf{G}_{\mathbf{2}} \mathbf{S}_{\mathbf{1}}$ & Shade net (50\%) + Time of sowing (September) \\
\hline $\mathbf{G}_{\mathbf{1}} \mathbf{S}_{\mathbf{2}}$ & Open field condition + Time of sowing (October) \\
\hline $\mathbf{G}_{\mathbf{2}} \mathbf{S}_{\mathbf{2}}$ & Shade net (50\%) + Time of sowing (October) \\
\hline $\mathbf{G}_{\mathbf{1}} \mathbf{S}_{\mathbf{3}}$ & Open field condition + Time of sowing (November) \\
\hline $\mathbf{G}_{\mathbf{2}} \mathbf{S}_{\mathbf{3}}$ & Shade net (50\%) + Time of sowing (November) \\
\hline $\mathbf{G}_{\mathbf{1}} \mathbf{S}_{\mathbf{4}}$ & Open field condition + Time of sowing (December) \\
\hline $\mathbf{G}_{\mathbf{2}} \mathbf{S}_{\mathbf{4}}$ & Shade net (50\%) + Time of sowing (December) \\
\hline $\mathbf{G}_{\mathbf{1}} \mathbf{S}_{\mathbf{5}}$ & Open field condition + Time of sowing (January) \\
\hline $\mathbf{G}_{\mathbf{2}} \mathbf{S}_{\mathbf{5}}$ & Shade net (50\%) + Time of sowing (January) \\
\hline $\mathbf{G}_{\mathbf{1}} \mathbf{S}_{\mathbf{6}}$ & Open field condition + Time of sowing (February) \\
\hline $\mathbf{G}_{\mathbf{2}} \mathbf{S}_{\mathbf{6}}$ & Shade net (50\%) + Time of sowing (February) \\
\hline $\mathbf{G}_{\mathbf{1}} \mathbf{S}_{\mathbf{7}}$ & Open field condition + Time of sowing (March) \\
\hline $\mathbf{G}_{\mathbf{2}} \mathbf{S}_{\mathbf{7}}$ & Shade net (50\%) + Time of sowing (March) \\
\hline $\mathbf{G}_{\mathbf{1}} \mathbf{S}_{\mathbf{8}}$ & Open field condition + Time of sowing (April) \\
\hline $\mathbf{G}_{\mathbf{2}} \mathbf{S}_{\mathbf{8}}$ & Shade net (50\%) + Time of sowing (April) \\
\hline $\mathbf{G}_{\mathbf{1}} \mathbf{S}_{\mathbf{9}}$ & Open field condition + Time of sowing (May) \\
\hline $\mathbf{G}_{\mathbf{2}} \mathbf{S}_{\mathbf{9}}$ & Shade net (50\%) + Time of sowing (May) \\
\hline
\end{tabular}


Table.2 Effect of different months of sowing and cultivation condition on leaf area $\left(\mathrm{cm}^{2}\right)$ and Leaf Area Index (LAI)

\begin{tabular}{|c|c|c|c|c|c|}
\hline \multirow{3}{*}{$\begin{array}{c}\text { S. } \\
\text { No }\end{array}$} & \multirow{3}{*}{$\begin{array}{l}\text { Time of } \\
\text { sowing } \\
\text { (S) }\end{array}$} & \multicolumn{2}{|c|}{ Condition (G) } & \multicolumn{2}{|c|}{ Condition (G) } \\
\hline & & Open (G1) & Shade (G2) & Open (G1) & Shade (G2) \\
\hline & & \multicolumn{2}{|c|}{ Leaf area $\left(\mathrm{cm}^{2}\right)$} & \multicolumn{2}{|c|}{ Leaf Area Index (LAI) } \\
\hline 1 & September & 34.06 & 40.29 & 0.114 & 0.134 \\
\hline 2 & October & 35.04 & 40.84 & 0.117 & 0.136 \\
\hline 3 & November & 33.12 & 39.87 & 0.110 & 0.133 \\
\hline 4 & December & 31.19 & 39.01 & 0.104 & 0.130 \\
\hline 5 & January & 32.98 & 37.12 & 0.110 & 0.124 \\
\hline 6 & February & 30.17 & 34.68 & 0.101 & 0.116 \\
\hline 7 & March & NA & 30.34 & NA & 0.101 \\
\hline 8 & April & NA & 28.90 & NA & 0.096 \\
\hline 9 & May & NA & 38.67 & NA & 0.129 \\
\hline \multicolumn{2}{|c|}{ Mean } & 32.76 & 36.64 & 36.64 & 0.122 \\
\hline \multicolumn{2}{|c|}{ SE(d) } & 0.8497 & 0.7109 & 0.7109 & 0.0036 \\
\hline \multicolumn{2}{|c|}{$\mathrm{CD}(\mathrm{P}=\mathbf{0 . 0 5})$} & $1.8933 * *$ & $1.5070 * *$ & $1.5070 * *$ & $0.0076 * *$ \\
\hline \multicolumn{6}{|c|}{ NS - Non Significant and ** - Highly significant } \\
\hline
\end{tabular}

Table.3 Effect of different months of sowing and cultivation condition on SPAD value and Nitrate Reductase Activity $\left(\mu \mathrm{g} \mathrm{NO} \mathrm{g}^{-1} \mathrm{~h}^{-1}\right)$

\begin{tabular}{|c|c|c|c|c|c|}
\hline \multirow{3}{*}{$\begin{array}{c}\text { S. } \\
\text { No }\end{array}$} & \multirow{3}{*}{$\begin{array}{l}\text { Time of } \\
\text { sowing } \\
\text { (S) }\end{array}$} & \multicolumn{2}{|c|}{ Condition (G) } & \multicolumn{2}{|c|}{ Condition (G) } \\
\hline & & Open (G1) & Shade (G2) & Open (G1) & Shade (G2) \\
\hline & & \multicolumn{2}{|c|}{ SPAD } & \multicolumn{2}{|c|}{ Nitrate Reductase Activity $\left(\mu \mathrm{g} \mathrm{NO} \mathrm{g}^{-1} \mathrm{~h}^{-1}\right)$} \\
\hline 1 & September & 32.81 & 42.81 & 312.27 & 287.06 \\
\hline 2 & October & 33.64 & 43.64 & 314.42 & 283.68 \\
\hline 3 & November & 32.29 & 43.29 & 318.49 & 287.09 \\
\hline 4 & December & 32.16 & 42.16 & 317.21 & 283.75 \\
\hline 5 & January & 33.02 & 43.02 & 321.68 & 287.17 \\
\hline 6 & February & 32.89 & 42.91 & 318.09 & 298.79 \\
\hline 7 & March & NA & 42.70 & NA & 298.16 \\
\hline 8 & April & NA & 42.09 & NA & 298.89 \\
\hline 9 & May & NA & 43.24 & NA & 281.66 \\
\hline \multicolumn{2}{|c|}{ Mean } & 32.80 & 42.87 & 317.03 & 289.58 \\
\hline \multicolumn{2}{|c|}{$\mathrm{SE}(\mathrm{d})$} & 0.6734 & 0.6118 & 3.2847 & 7.9711 \\
\hline \multicolumn{2}{|c|}{$\mathrm{CD}(\mathbf{P}=\mathbf{0 . 0 5})$} & 1.5004 NS & $1.2970 \mathrm{NS}$ & $7.3188 \mathrm{NS}$ & $16.8983 \mathrm{NS}$ \\
\hline \multicolumn{6}{|c|}{ NS - Non Significant and $* *$ - Highly significant } \\
\hline
\end{tabular}


Table.4 Effect of different months of sowing and cultivation condition on Soluble Protein and Ascorbic Acid

\begin{tabular}{|c|c|c|c|c|c|}
\hline \multirow{3}{*}{$\begin{array}{c}\text { S. } \\
\text { No }\end{array}$} & \multirow{3}{*}{$\begin{array}{l}\text { Time of } \\
\text { sowing } \\
\text { (S) }\end{array}$} & \multicolumn{2}{|c|}{ Condition (G) } & \multicolumn{2}{|c|}{ Condition (G) } \\
\hline & & Open (G1) & Shade (G2) & Open (G1) & Shade (G2) \\
\hline & & \multicolumn{2}{|c|}{ Soluble Protein } & \multicolumn{2}{|c|}{ Ascorbic Acid } \\
\hline 1 & September & 2.47 & 2.56 & 97.65 & 97.23 \\
\hline 2 & October & 2.48 & 2.59 & 98.69 & 97.22 \\
\hline 3 & November & 2.46 & 2.55 & 98.29 & 97.22 \\
\hline 4 & December & 2.45 & 2.53 & 98.31 & 97.24 \\
\hline 5 & January & 2.47 & 2.56 & 95.98 & 95.19 \\
\hline 6 & February & 2.44 & 2.53 & 95.66 & 95.07 \\
\hline 7 & March & NA & 2.49 & NA & 97.42 \\
\hline 8 & April & NA & 2.48 & NA & 97.45 \\
\hline 9 & May & NA & 2.54 & NA & 96.17 \\
\hline \multicolumn{2}{|c|}{ Mean } & 2.46 & 2.54 & 97.43 & 96.69 \\
\hline \multicolumn{2}{|c|}{$\mathrm{SE}(\mathrm{d})$} & 0.0485 & 0.0498 & 1.2720 & 1.5966 \\
\hline \multicolumn{2}{|c|}{$\mathrm{CD}(\mathbf{P}=0.05)$} & 0.1081 NS & 0.1056 NS & 2.8342 NS & 3.3846 NS \\
\hline & & NS - No & iificant and * & hly significa & \\
\hline
\end{tabular}

Effect of different months of sowing and cultivation condition on Soluble Protein and Ascorbic Acid were presented in Table 4. Soluble protein was not influenced by the different months of sowing and growing conditions as the statistical analysis resulted in non-significant values. The soluble protein content ranged from $2.59 \mathrm{mg} / 100 \mathrm{~g}$ (October sown seeds under shade net) to $2.44 \mathrm{mg} / 100 \mathrm{~g}$ (February sown crop under open field condition). The highest ascorbic content was $98.69 \mathrm{mg} / 100 \mathrm{~g}$ during October under open condition. Whereas it was lowest during January $95.19 \mathrm{mg} / 100 \mathrm{~g}$ under shade net condition.

Physical environment has profound influence on growth, biomass partitioning and ultimately the yield of coriander. Temperature, humidity, rainfall and other meteorological factors may individually or collectively limit the plant growth and production. Time of sowing controls the crop phenological development along with efficient conversion of biomass into economic yield (Khichar and Niwas, 2006). Vegetative growth parameters were found to be better in shade net condition which might be due to favourable growing condition. Plants under shade produced more number of leaves which had increased photosynthetic area through the action of cell division and cell enlargement. These corroborates the findings of previous researchers (Sinha et al., 2005).

The result of the present study showed that, there is no significant effect of time of sowing and growing conditions on biochemical parameters viz., total chlorophyll content, soluble protein content and nitrate reductase activity in plants.

Seasonal evaluation of SPAD values did not show significant differences under both the growing condition. However, the total chlorophyll content was higher in the shade 
grown coriander leaves when compared to open field condition. This is consistent with the results already reported for various species which indicated higher chlorophyll content in the plants grown under shaded condition in cluster beans (Vandana and Bhatt, 1999), (Kosma et al., 2013) and (Vyas et al., 1996). However, noting that higher shading intensity resulted in higher SPAD values and higher chlorophyll concentration (Legarrea et al., 2010) and (Jang et al., 2014) Shade-plants develop acclimation strategies, including larger and thinner leaves which present even a three-fold increase in chlorophylls (Adamson et al., 1991); (Taiz and Zeiger, 2002).

In general, the shade grown plant leaves contains more chlorophyll $b$ than the open field grown plants. The increase in the chlorophyll $b$ relative proportion is an important characteristic of shaded environments because it acquires the photon energy in longer wavelengths, therefore, with less energy, transfers it to chlorophyll $a$ which act effectively in the photosynthesis photochemical reactions (Whatley and And Whatley, 1981). The increased total chlorophyll content in shade grown plants might be due to increase in number and size of chloroplast, the amount of chlorophyll per chloroplast and/or better grana. The increase in chlorophyll content by shading might be due to the increased proportion of grana per plastid volume in the chloroplast in beans (Crookston et al., 1975).

The marked increase in leaf chlorophyll content in the 50\% and $70 \%$ shaded conditions demonstrate the plant's ability to maximize the light harvesting capacity under light-deficit conditions and the efficient use of light captured in photosynthesis with decreased respiration costs for maintenance (Mariko Kura-Hotta et al., 1987); (Lei et al., 1996); (Yajuan et al., 2009); (Mohammad
Reza Boorboori et al., 2012). The concentration of chlorophyll per unit area or weight of leaves would have increased with decreased light intensity until the intensity was low (below the saturation point) for the plants to survive. The chlorophylls are usually synthesized and photo-oxidized in the presence of light. Nonetheless, the excess of light can cause greater degradation and consequently, a reduction in the levels of total chlorophyll (De Carvalho Gonçalves et al., 2005).

The low chlorophyll content in the leaves of open field grown coriander leaves might be due to the destruction of the chloroplast pigment under high light intensity and higher temperature (Radha et al., 1980).

The growing condition and time of sowing did not show any significant difference in the soluble protein content of the leaves. However, the shade net grown plants recorded higher soluble protein content than the open field grown plants (Dabhi, 2015). In general, protein content increased and carbohydrate content decreased with shading (Tikomirov et al., 1976).

There is no significant difference in Nitrate reductase activity of the coriander leaves which is grown under different growing condition. However, the plants grown under open field condition recorded higher nitrate reductase activity when compared with the plants grown under shade net condition. The result of the present study confirms the findings in celery (Wojciechowska and Siwek, 2006). This reduction in the Nitrate reductase activity in shade net grown plants may be due to the influence of light intensity. Light is the main external factor which modifies NR activity in leaves on posttranslation level, as in result of rapid plant shading the activity of this enzyme quickly decreases (Huber et al., 1992), (Lillo, 1984). 
From the above outcomes we can conclude that when the light intensity is increased the nitrate reductase activity of the leaf also will increase.

Ascorbic acid is synthesized from photosynthesis-produced sugars (Lee and Kader, 2000). Thus, a lower ascorbic acid content of the fruits produced in a protected environment is probably caused by the lower luminosity in the environment, which may have reduced the production of sugar, a substrate that is used in the synthesis of ascorbic acid. Leaf calcium and ascorbic acid composition of spinach (Spinacea oleracea L.) and lettuce (Lactuca sativa L.) increases with minor reduction in temperature and high light intensities due to climatic or weather changes. Ascorbic acid concentration also generally increases with increased exposure to light, particularly in leafy greens (Oyama et al., 1999); (Weerakkody, 2003). From the study it can be concluded that, to obtain high nutritive values of coriander October season under open field condition and year round production under shadenet with slight physiological and biochemical during summer can be suggested.

\section{References}

Adamson, H. Y., Chow, W. S., Anderson, J. M., Vesk, M., and Sutherland, M. W. (1991). Photosynthetic acclimation of Tradescantia albiflorato growth irradiance: morphological, ultra structural and growth responses. Physiological Plant, 82, 353359.

Anonymous. (1975). Official and tentative methods of analysis. Association of official Analytical Chemistry, Washington, D. C, U.S.A. 497-499.

Crookston, R., TreharneKj, Ludford P and Ozbun JL (1975). Response of beans to shading. Crop Science, 15, 412-416.

Dimri, B. P., Khan, M. N., and Narayna, M. R. (1976). Some promising selections of Bulgarian coriander for seed and essentialoil with note on cultivation and distillation of oil. Indian Perfumer, 20(1), 14-21.

Directorate of arecanut and spices development, 2017, dasd.gov.in

Dabhi, J. S. (2015). Varietial performance of spinach beet under different environmental conditions. The ecoscan, VIII, 429-434.

De Carvalho Gonçalves, J.F., De Sousa Barreto, D. C., Dos Santos Jr, U. M., Fernandes, A. V., Barbosa Sampaio, P. D. T., and Buckeridge, M. S. (2005).

Growth, photosynthesis and stress indicators in young rosewood plants (Anibarosaeodora Ducke) under different light intensities. Brazil Journal of Plant Physiology, 17, 325334

Huber, S., Huber Jl, Campbell WH and Margaret GR. (1992). Comparative studies of light modulation of nitrate reductase and sucrose-phosphate synthatase Activities in spinach leaves.Plant Physiol, 100, 706-712

Jang, Y., Mun, B., Do, K., Um, Y., and Chun, C. (2014). Effects of photosynthetic photon flux and carbon di oxide concentration on the photosynthesis and growth of grafted pepper transplants during healing and acclimatization. Horticulture Environment and Biotechnology 55, 387-396.

Khichar, M. L., and Niwas, R. (2006). Microclimatic profiles under different sowing environments in wheat. J. Agromet, 8, 201-209

Kosma, C., Trianta fyllidis, V., Papasavvas, A., Salahas, G., and Patakas, A. (2013). Yield and nutritional quality of green house lettuce as affected by shading and cultivation season. Emir. J. Food Agric, 25, 974-979

Lee, S. K., and Kader, A. A. (2000). Pre harvest and post harvest factors influencing vitamin $\mathrm{C}$ content of horticultural crops. Postharvest Biology and Technology, 20(3), 207-220.

Legarrea, S.,Karnieli, A., Fereres, A., and Weintraub, P. G. (2010). Comparison of UV absorbing nets in pepper crops: spectral properties, effects on plants and pest control. Photochemistry and Photobiology, 86, 324-330.

Lei, T. T., Xabuchi, R., Kitao, M., and Koike. T. (1996). Functional relationship between 
chlorophyll content and leaf reflectance and light-capturing efficiency of Japanese forest speeies. Physiol. Plant., 96, 411-418.

Lowry, O. H., Rose Brought, L. A., and Randall., F. R. J. (1957). Protein measurement with folin phenol measurement with folin reagent. J. Biol. Chem., 193, 455-461.

Mariko Kura-Hotta, Kazuhiko Satoh and Katoh, S. (1987). Relationship between photosynthesis and chlorophyll content during leaf senescence of rice seedlings. Plant and Cell Physiology, 28 (7,1), 13211329.

Mohammad RB, D. Eradatmand Asli and Tehran, M. M. (2012). Effect of micronutrient application by different methods on yield, morphological traits and grain protein percentage of barley (Hordeum vulgare L.) in green house conditions. Revista Científica UDO Agrícola, 12(1), 1217-134

Nicholas, J. C., Harper, J. E and Hageman., R. H. (1976). Nitrate reductase activity in soybeans. Pl. Physiol., 58, 731-735.

Oyama, H and Shinolara, Y. I. (1999). Effect of air temperature and light intensity on beta carotene concentration in spinach and lettuce. J. Japan. Soc. Hort. Sci., 68(2), 414420.

Panse, V. G., and Sukhatme, P. V. (1985). Statistical methods for Agricultural workers Indian Council of Agricultural Research, NewDelhi.

Radha, T., Aravindakshan, M and Balakrishnan, S. (1980). Effect of different light intensities on vegetative characters and leaf analysis of pineapple variety 'kew'. Agric. Res. J. Kerala, 18(2), 147-151

Shankaracharya, N. B and Natarajan, C. P. (1971). Leafy spices-chemical composition and uses. Indian Food Packer, 25(2), 29-40

Sinha, S., Pandey, K., Gupta, A. K and Bhatt, K. (2005). Accumulation of metalsin vegetables and crops grown in the area irrigated with river water. Bulletin of Environmental Contamination and Toxicology, 74(1), 210-218.

Taiz, L and Zeiger, E. (2002). Plant Physiology. 3rd ed. Sunderl and: Sinauer Associates, Inc.

Tikomirov, A. A., Zolotukhin, J. C and Yasidko., A. F. (1976). Effect of light regime on productivity and quality of the harvest of radish. Soviet $\mathrm{Pl}$. Physiol, 23, 27-31

Vandana and Bhatt, R. K. (1999). Physiological changes in Sesbania species to reducing light intensities. Journal of Agronomy and Crop Science, 182(1), 43-47.

Vyas, S. P., Kathju S, Garg B K and Lahiri AN. (1996). Response of cluster bean genotypes to shade. Indian J. Plant Physiol., 1, 234238

Whatley, J., M and Whatley, F. R. (1981). Chloroplast evoluation. New phytol, 87,233-247.

Williams, R. F. (1946). The physiology of plant growth with special reference to the concept of net assimilation rate. Ann. Bot., 1, 41-72.

Wojciechowska, R and Siwek, A. P. (2006). The effect of shading on nitrate metabolism in stalk sand blades of celery leaves (Apium graveolens L.var. dulce). Folia horticulturae Ann, 18/2, 25-35.

Yadava, U. L. (1986). A rapid and non destructive method to determine chlorophyll in intact leaves. Hort. Sci., 21, 1449-1140.

Yajuan, D. A., Zonggen Shenb, Ying Liua, Lanlan Wanga, David Hannawayc and Lu, H. (2009). Effects of shade treatments on the photosynthetic capacity, chlorophyll fluorescence and chlorophyll content of Tetrastigma hemsleyanum Dielset Gilg. Environmental and Experimental Botany, $65,177-182$.

\section{How to cite this article:}

Mohanalakshmi, M., M. Boomiga and Gowtham, T. 2019. Effect of Season and Growing Condition on Biochemical and Physiological Parameters of Coriander (Coriandrum sativum L.). Int.J.Curr.Microbiol.App.Sci. 8(08): 2161-2168. doi: https://doi.org/10.20546/ijcmas.2019.808.252 